\title{
"KEHIDUPAN SEKERUH AIR DI LADANG SAWIT" (Kajian Kemiskinan Masyarakat Perbatasan, Kabupaten Aceh Singkil)
}

\author{
Muhajir Al Fairusy \\ (Sosiologi Agama Fakultas Ushuluddin UIN Ar Raniry)
}

\begin{abstract}
Abstrak
Kemiskinan, selalu menjadi isu magnet untuk diperbincangkan, didiskusikan, dikaji, hingga berujung pada rekomendasi kebijakansebagai upaya menuntaskannya. Dalam kajian sosial, kemiskinan sering dibenturkan dengan pandangan struktural dan kultural sebagai sebab dari potret kehidupan getir tersebut, yang hadir di tengah komunitas masyarakat. Kajian ini, dihidangkan sebagai upaya mendiskusikan kembali potret kemiskinan di tengah masyarakat perbatasan-Aceh Singkil. Sebagai wilayah perbatasan, Aceh Singkil sering mengalami kompleksitas persoalan, terutama di bidang ekonomi (selain banjir dan konflik antar-umat beragama). Padahal, kabupaten ini dipandang sebagai salah satu kawasan penghasil sawit terbesar di Aceh. Permasalahan yang dikemukakan di sini adalah Bagaimana potret makna kemiskinan bagi masyarakat perbatasan, dan sebab munculnya kemiskinan. Tujuan penelitian ini adalah berusaha memahami dan menjelaskan fenomena kemiskinan, makna dari individu miskin, dan lahirnya solusi pengentasan kemiskinan-berbasis pendekatan etnografi, tanpa mengabaikan interkoneksi metode lain. Kajian ini, dipotret dan dinarasikan dengan pendekatan kualitatif, melakukan observasi, wawancara mendalam dengan beberapa informan, serta dilakukan dokumentasi (berupa foto) untuk mendukung hasil kajian kemiskinan di Kabupaten Aceh Singkil. Hasil penelitian menunjukkan bahwa, muncul beberapa sebab kemiskinan berdasar etik dan emik masyarakat. Di sisi lain, juga turut bermunculan situasi kemiskinan yang didominasi oleh sebab struktural. Karena itu, solusi yang ditawarkan pun dalam upaya mereduksi adalah dengan pola mengubah pola perlakuan terhadap masyarakat (bantuan sosial, dan kebijakan pembangunan) dengan memahami akar kemiskinan di perbatasan.
\end{abstract}

Kata Kunci : Kemiskinan, Masyarakat Perbatasan Singkil. 


\section{PENDAHULUAN}

Kantong-kantong kemiskinan di Indonesia, sering bermunculan di wilayah yang jauh dari episentrum birokrasi dan perencanaan pembangunan. Jika pada skala nasional, maka wilayah yang kian jauh dari ibukota (Jakarta) cenderung diklaim sebagai teritorial yang lamban pembangunannya, sebut saja Papua dan Aceh. Pun demikian, di tingkat provinsi-kabupaten yang semakin renggang dan jauh dari jangkauan pusat ibukpta provinsi, cenderung dianggap sebagai wilayah yang luput dari keseriusan pembangunan, dan rentan kemiskinan. Fenomena ini, berlaku di setiap provinsi yang ada di Indonesia, termasuk Aceh. Kabupaten Aceh Singkil misalnya, sebagai salah satu kabupaten perbatasan, dan letaknya paling ujung teritorial Aceh, terkesan lamban laju pembangunan, mendapat stereotipe daerah tertinggal, dan bermunculan potret kemiskinan sebagai konfigurasi komunitas warganya. Apalagi, gempuran perusahaan besar perkebunan sawit, kian menempatkan banyak masyarakat terjebak menjadi buruh, dan sulit mengembangkan diri pada taraf sejahtera.

Dalam konteks kultur manusia Aceh secara etnik, mereka yang terjebak pada situasi kemiskinan, tampak sadar secara sosial, bagaimana mengidentifikasi diri sebagai orang Miskin (Aceh ; gasien, papa). Dalam beberapa tutur Aceh yang lain, orang miskin hadir dalam struktur sosial-yang menunjukkan kelasnya, hingga dituntut membutuhkan perhatian dari pihak lain. Kemiskinan di Aceh, sering hadir seiring menguatnya kelas sosial, dan kepemilikan materi yang didominasi oleh individu tertentu, hingga menempatkan orang miskin di tingkat bawah. Pun di wilayah tertentu, seperti pesisir, kemiskinan kerap dihadirkan dengan potret rumah tak layak huni, lemahnya pendidikan, hubungan kerja, hingga kepemilikan alat produksi. Di wilayah pegunungan, kemiskinan dihadirkan oleh terputusnya akses pasar, dan kepemilikan alat produksi.

Secara sosial dan politik, potret kemiskinan dianggap salah satu indikator penting mengukur laju perkembangan, kesejahteraan dan kemajuan sebuah negara. Meskipun, kemiskinan itu sendiri absurd di tengah gempita pembangunan. Atribut dan ukuran kemiskinan juga berbeda antar-komunitas, yang ragam topografis wilayahnya, antara komunitas satu negara dengan negara lain, bahkan antara satu provinsi dengan provinsi lain di Indonesia. Apalagi, sistem demokrasi yang umum dipakai oleh banyak negara dewasa ini, khusus untuk Indonesia, dianggap belum menjadi sistem yang mampu memberantas 
kemiskinan (Lihat Utomo, 2004 ; 109-111). Karena itu, solusi untuk menentaskan kemiskinan dianggap semakin rumit, apalagi laju penduduk tak dapat dibendung.

Di samping itu, menarik melihat liputan Republika (11 Desember 2014 ; 9), terutama di kolom Sudut Pandang, tulisan yang ditulis oleh Muhammad Djibril, dengan judul "Yang Rentan Miskin," bahwa secara statistik, angka kemiskinan Indonesia turun, meski melambat sekitar 0.7 persen, selama rentang 2012-2013. Indikator yang dipakai penulis adalah menyandingkan data BPS,

“... bahwa jumlah penduduk Indonesia yang miskin mencapai 28.28 juta jiwa, setara sekitar $11.25 \%$, data Maret 2014. Dalam data tersebut, terungkap, jumlah penduduk miskin Indonesia berkurang dari $11.46 \%$ menjadi $11.25 \%$, padahal pada September 2013, jumlahnya mencapai 28.60 juta jiwa. Jika merujuk pada data Bank Dunia, sebanyak 68 juta penduduk Indonesia rentan miskin. Dari data BPS, kemiskinan dapat dilihat dari kemampuan seseorang dalam memenuhi kebutuhan ekonominya, dalam hal dasar makanan, bukan aspek pengeluaran. Malah, Tim Nasional Percepatan Penanggulangan Kemiskinan (TNP2K) mencatat pada 2013, yang rentan miskin mencapai 96.7 juta jiwa atau sebanyak 24.7 juta rumah tangga. BPS mencatat garis kemiskinan pada September 2013 sebesar Rp 292.951 per kapita per bulan. Langkah kemudian adalah mendongkrak pendapatan kelompok rentan miskin. Salah satu caranya adalah tersedianya lapangan kerja." (Djibril, Republika, Desember 2014)

Paragraf di atas, ukuran statistik yang menjadi salah satu acuan setiap penelitian, tentu memberikan gambaran dinamika kemiskinan (naik dan turun). Memang, data BPS masih menjadi data "sakral dan vital" untuk mengukur kemiskinan, atau standar garis kemiskinan. Namun, lewat pendekatan kualitatif (penelitian yang dilaksanakan), nantinya akan diukur secara etik dan emik-kausalitas kemiskinan, yang muncul dari masyarakat miskin sendiri, sesuai kultur dan struktur yang berlaku. Apalagi, sejalur yang dikatakan oleh Hendri Saparni, Direktur Eksekutif Core Indonesia (masih di Republika, 2014 ; 18), bahwa harus dibedakan orang yang berada di bawah garis kemiskinan, dan orang yang mendekati kemiskinan. Jika, hanya menyelesaikan orang yang berada di bawah garis kemiskinan, tinggal diberi beras saja bisa selesai. Namun, untuk menanggulangi orang yang mendekati kemiskinan, salah satu solusinya adalah menciptakan lapangan kerja 
yang masif. Tentunya, untuk mencapai solusi yang dimaksud, harus muncul interkoneksi metode penelitian, dan disipilin paradigma.

Mesipun begitu, kajian tentang kemiskinan dalam ranah sosial (dengan pendekatan kualitatif), tentu bukan hal baru, termasuk dari sisi kajian etnografi (Lihat Kusnadi, 2002, 2003. Ghofur, 2009, dan Siwanto, 2008 ). Pun, kajian mengenai kemiskinan terus dilakukan untuk menemukan titik celah menuntaskan potret kesenjangan sosial tersebut. Pentingnya kajian etnografi mengingat variannya kultur dalam masyarakat membangun persepsi miskin, dan sebab munculnya kemiskinan yang cenderung berbeda. Seperti kata Spradley, dalam bukunya Metode Penelitian Etnografi, "Jika anda melihat riak ombal di lautan, maka etnografi menyeleminya hingga ke dasar lautan." Pun fenomenan kemiskinan, tak cukup dilihat sepintas, dia harus dilakukan upaya penelitian partisipan-guna menggali lebih dalam makna, dan fenomena kemiskinan secara mendalam.

Kemiskinan di Aceh, terutama kabupaten yang sulit di akses seperti Aceh Singkil, tentu menjadi persoalan yang harus diselesaikan oleh ragam komponen, baik elite negara, hingga akademisi (meskipun tidak komprehensif). Melimpahnya Sumber Daya Alam, kuatnya klen kekerabatan, dan meningkatnya jumlah sarjana (pendidikan) dari 150 Perguruan Tinggi, menjadi persoalan baru, kenapa kemiskinan masih tinggi. Apalagi, di tengah melimpahnya dana yang mengalir ke Aceh pascatsunami dan MoU antara RI dan GAM, kemiskinan menjadi borok yang patut dipertanyakan. Apalagi, jika di lapangan-masih ditemukan warga yang hidup tak layak, meskipun ukuran derasnya dana-tak bisa dijadikan klaim terhapusnya kemiskinan, karena fenomena sosial ini juga identik dengan kultural komunitas. Karena itu penelitian dengan menggunakan metode kaulitatif, mengharuskan peneliti terlibat secara aktif (partisipan) di tengah masyarakat-yang menjadi informan. Nantinya, diharapkan akan memunculkan narasi kausalitas fenomena kemiskinan, terutama menemukan akar kemiskian di wilayah perbatasan Aceh.

\section{Metode Penelitian}

Penelitian untuk mengumpulkan data tentang fenomena kemiskinan, di salah satu kecamatan, Kabupaten Pidie Jaya, dengan menggunakan metode penelitian kualitatif. Teknik pengambilan data dengan teknik observation (observasi) dan depth interview (wawancara mendalam). Peneliti juga melakukan perekaman data visual dengan pemotretan memanfaatkan kamera foto, nantinya data visual akan 
ditampilkan dalam tulisan ini. Sebelum penelitian lapangan (field research) dilaksanakan, terlebih dahulu peneliti mengkaji berbagai literatur yang berhubungan dengan kajian kemiskinan, dan masyarakat yang akan diteliti.

Strauss \& Corbin (2003; 10-11) mengatakan bahwa, “Teori yang grounded adalah teori yang diperoleh secara induktif dari penelitian tentang fenomena yang dijelaskannya. Karenanya teori ini ditemukan, disusun, dan dibuktikan untuk sementara melalui pengumpulan data yang sistematis, dan analisis data yang berkenaan dengan fenomena itu. Dengan demikian pengumpulan data, analisis, dan teori saling terkait dalam hubungan timbal-balik. Peneliti tidak memulai penyelidikan dengan satu teori tertentu, lalu membuktikannya, tetapi dengan suatu bidang kajian dan hal-hal yang terkait dengan bidang tersebut".

Penelitian ini adalah penelitian kualitatif sehingga yang lebih dipentingkan adalah kualitas dan kedalaman data. Karena itu, Peneliti tidak memanfaatkan kuisioner sebagai instrumen penelitian, tidak ada hipotesa, tidak mencari korelasi antar variabel, tidak ada sebab dan akibat (causality), tidak ada prosentase responden terhadap populasi, dan tidak ada istilah responden sebagai nara sumber pengumpulan data. Semuanya, adalah poin-poin ciri khas pada metode penelitian kuantitatif. Sebaliknya, peneliti memanfaatkan interview guidance (panduan atau pedoman wawancara) sebagai instrumen penelitian, yang bersifat fleksibel dan menyesuaikan dengan kondisi di lapangan saat melakukan wawancara mendalam. Nara sumber penggalian data adalah key persons dan informan, bukan responden. Penggalian data difokuskan pada makna (meaning) yang ada di dalam pikiran informan terhadap situasi kemiskinan yang dia pahami, dia alami, atau dia saksikan.

Untuk mencapai lokasi penelitian, maka dari Kota Banda Aceh ke Kabupaten Aceh Singkil, peneliti melakukan perjalanan darat, dengan jarak tempuh \pm 15 jam-menggunakan angkutan mini bus. Situasi jauhnya jarak Banda Aceh menuju Singkil, menjadi tantangan tersendiri bagi peneliti. apalagi, saat tiba di Kota Subulussalam, armada angkutan (L 300) tidak lantas menuju Singkil (yang membutuhkan waktu 2 jam 30 menit perjalanan lagi), armada penumpang tersebut, terlebih dahulu berhenti untuk istirahat dan sarapan selama 30 menit, dan kemudian melanjutkan lagi perjalanan ke Singkil. Perjalalan ke Singkil, melintasi 7 Kabupaten/Kota (Aceh Besar, Aceh Jaya, Aceh 
Barat, Nagan Raya, Aceh Barat Daya, Aceh Selatan, dan Kota Subulussalam). Sepanjang perjalanan dari Aceh Barat hingga ke Singkil, perkebunan sawit tampak membentang luas, sebagai indikasi kultur masyarakat setempat merupakan bagian dari industri perkebunan sawit.

Di lokasi penelitian, peneliti terlebih dulu melakukan penelitian di pusat Kabupaten Aceh Singkil, untuk mengumpulkan data mengenai kemiskinan di kabupaten yang baru yang langsung berbatasan dengan Provinsi Sumatera Utara. Setelah itu, baru peneliti masuk dan fokus bekerja di Kecamatan yang dipilih sebagai salah satu titik rawan kemiskinan (berdasar data dari kabupaten), selanjutnya melakukan kajian di sana selama beberapa Minggu.

\section{Pembahasan}

\section{A. Potret Kemiskinan ; Struktural, Kultural dan Kemampuan akses lima kapital}

Aceh sebagai salah satu provinsi-bagian dari Republik Indonesia. Tentunya, juga tak luput dari persoalan kemiskinan. Meskipun, di lapangan, saat berhadapan dengan masyarakat sulit sekali menentukan posisi "miskin" di Aceh, jika dikomparasikan dengan kehidupan di Jakarta misalnya, yang kontras menampilkan kemiskinan-dengan atribut kumuh, pemulung, dan gaya hidup yang dilebelkan miskin. Di Aceh, aroma kemiskinan baru dapat ditemukan, jika langkah sanggup berkunjung ke dalam pelosok (wilayah pegunungan dan pesisir) beberapa Kabupaten di Aceh. Dalam pelosok Aceh, rumah gubuk tak layak huni adalah atribut miskin yang dapat dipetakan langsung. Karena itu, dengan menggunakan akses lima kapital yang wajib dimiliki individu, nantinya akan dapat ditemukan gejala kemiskinan, setelah ditelusuri secara partisipan di titik-titik yang dianggap rawan kemiskinan, pada beberapa kabupaten di Aceh.

Memasuki wilayah Kabupaten Aceh Singkil, suguhan perkebunan sawit membentang luas di hadapan setiap pengunjung. Rentetan rumah di beberapa titik bermaterial kayu menjadi tontonan atribut potret ekonomi masyarakat setempat. Lalu lalang, truk pengangkut sawit yang bermuatan tandan sawih dalam bak penuhdengan mudah dijumpai di sepanjang jalan menuju ibukota Singkil. Beberapa jembatan berkonstruksi beton menjadi penghubung utama untuk menyebrang beberapa sungai lebar, di bawahnya menampilkan 
aktifitas-kebutuhan vital masyarakat pada air sungai yang tampak keruh, terutama untuk mandi dan mencuci pakaian.

Daerah yang pernah terkenal sebagai reproduksi cerita sejarah ini, didiami dan dimoninasi oleh masyarkat lintas etnik (Pakpak, Minang, Aceh dan Jawa). Sebagian besar masyarakat bermata pencaharian sebagai petani di perkebunan sawit, sebagian besar adalah buruh pada perusahaan industri sawit. Di wilayah pesisir, umumnya masyarakat bekerja sebagai nelayan penangkap ikan. Khusus kajian kemiskinan ini, saya hanya melibatkan diri dengan karakter masyarakat di lingkungan perkebunan sawit. Apalagi, masyarakat perkebunan, selain pola hidup masyarakatnya dalam mengatur aset ditentukan oleh perusahaan, juga klaim dirinya sebagai orang miskin lebih tinggi, dibanding wilayah pesisir Singkil.

Narasi ini, mengenai kehidupan masyarakat miskin di salah satu kecamatan-Aceh Singkil, Kecamatan Gunung Meriah. Kecamatan yang tampak luas ini, dan menjadi pusat perekonomian salah satu kotanya (Kota Rimo), justru menampilkan sisi getir di wilayah pedalaman dan beberapa kampung berbatasan dengan Kota Rimo. Dua kampung, yang saya ambil sebagai landasan penelitian adalah Kampung Cingkam dan Kampung Pertampakan. Narasi dalam kajian ini-saya akan menampilkan potret kemiskinan di dua Kampung tersebut, salah satu kampung merupakan kampung relokasi pascatsunami di Aceh tahun 2005.

Jika dilihat secara Sumber Daya Alam (SDA), kecamatan ini memiliki aset alam, representasi salah satu syarat agar setiap individu atau kelompok harus memiliki lima aset (livelihood assets), dan dapat melangsungkan kehidupan layak (bebas kemiskinan). Pun aset lain (penunjang mutlak) yang harus dimiliki oleh individu, agar bebas dari kemiskinan adalah aset manusia, aset sosial, aset fisik, dan aset finansial. Bentangan kebun sawit, ekosistem sungai, cukup untuk menempatkan kapital SDA terpenuhi. Hanya saja, status kepemilikan, menjadi persoalan, karena tak semua masyarakat (menurut geuchik setempat) memiliki aset seperti kebun sawit. Umumnya, masyarakat adalah buruh sawit dengan gaji kecil.

Namun demikian, ketersediaan aset alam tak didukung oleh kemampuan mengakses-akibat keterbukaan pada izin perusahaan yang dapat menguasai sebagian besar lahan sawit di kabupaten ini. Akibatnya, banyak masyarakat dimiskinan secara struktural. Selain itu, atribut kemiskinan muncul dari sisi kultural, di mana pola hidup 
masyarakat setempat yang menonjolkan tempat tinggal dengan potret sangat sederhana. Umumnya, rumah dibuat dari konstruksi kayu, dan terkesan kurang layak tinggal. Namun, sepertinya masyarakat setempat merasa nyaman dengan tempat tinggal demikian.

\section{B. "Rezeki Ada, Tapi Tak Tahu Cara Kami Mengelola" (Kesadaran Erosi SDM Penduduk Lokal)}

Tangga 04 September 2015, saya tiba di Kabupaten Aceh Singkil, seterunya-mencoba melacak kembali terkait kemiskinan (versi kecamatan) di Kecamatan Gunung Meriah. Tepat pukul 10.05, saya mengunjungi Kantor Kecamatan setempat. Dari data kecamatan, selanjutnya saya memilih dua gampong (dari 25 gampong) yang masuk kategori rentan dan parah tingkat kemiskinan menurut informasi dari sekretari kecamatan (Bapak Mustafa). Pemilihan dua gampong, juga sebagai strategi komparasi, untuk menemukan titik kemiskinan berdasarkan tipologi masyarakat di sana yang cenderung hiterogen. Pun demikian, pemilihan Kecamatan Gunung Meriah sebagai basis dan objek penelitian, didasari dari data statistik jumlah penerima beras miskin, dan jumlah penduduk terbanyak berdasar Dinas Sosial.

Luas Kecamatan Gunung Meriah berdasar data BPS Kabupaten Aceh Singkil, 2014 adalah $215 \mathrm{Km}^{2}$, sebelah utara berbatasan dengan Kecamatan Singkohor, sebelah selatan berbatasan dengan Kecamatan Singkil Utara, sebelah timur berbatasan dengan Kecamatan Simpang Kanan, dan sebelah barat berbatasan dengan Kecamatan Kota Baharu. Topografi keacamatan ini, berbentuk datar dan hanya sebagian gampong yang permukaan tanahnya berbukit. Jumlah penduduk Kecamatan Gunung Meriah berdasar statistik tahun 2013 adalah 38.191 jiwa, kepadatan penduduk 170 jiwa/ $\mathrm{Km}^{2}$. Berdasar data statistik pula, disebutkan bahwa kecamatan ini merupakan wilayah potensi yang cukup besar pada bidang pertanian.

Dari 25 gampong/desa dalam Kecamatan Gunung Meriah, dua gampong yang masuk dalam rawan dan kategori miskin, yaitu Gampong Pertampakan dan Gampong Cingkam. Kedua gampong letaknya berjauhan, dan arahnya berbeda. Gampong Cingkam, berdekatan dengan Kota Rimo (hanya berjarak 6 KM dari Rimo), Rimo merupakan salah satu kota paling aktif denyut nadi ekonominya di Aceh Singkil, sehingga kehidupan dan aktifitas paling menggeliat hanya tampak di Rimo, bahkan dibanding dengan pusat administrasi di Kecamatan Singkil sendiri. 
Pada hari pertama observasi, Meskipun, tak jauh dari Rimo, Gampong Cingkam masuk dalam kategori rawan kemiskinan berdasar informasi kecamatan. Terdapat 117 KK di Gampong Cingkam, lokasinya dibelah oleh jalan menuju lokasi Transmingrasi dan Perkebunan/Perusahaan Sawit. Gampong Cingkam, termasuk kawasan yang memiliki potensi sumber daya natural cukup, diantaranya ada sumber air bersih yang terus mengalir dari Gunung Solok, lahan perkebunan sawit yang luas, tersedianya pasir berkualitas, dan adanya danau yang sedia menyimpan ekosistem ikan air tawar. Sumber daya natural ini, merupakan salah satu aset yang telah dimiliki warga Cingkam dalam upaya mereduksi kemiskinan. Namun demikian, wajah kemiskinan justru masih tampak di Cingkam, situasi ini terlihat dari banyaknya rumah bantuan, potret kehidupan warga yang terkesan kumuh, dan keluhan akan terbatasnya biaya hidup.

Saat pertama sekali tiba di Cingkam, saya terus mencoba menemui beberapa warga yang ada di Gampong Cingkam. Diantara warga yang kami temui bernama Aswan Pohan (59 tahun) dan Salbiah (38 tahun). Keduanya merupakan warga Gampong Cingkam yang bekerja sebagai petani sawit dan nelayan di danau yang ada di gampong setempat. Aswan Pohan tinggal di rumah bantuan rehabilitasi, bersama seorang istri dan anaknya. Sehari-hari ia merupakan buruh di perkebunan sawit, jika ada waktu longgar ia ke danau mencari ikan air tawar di depan rumahnya.

Menurut Aswan, sebagian besar penduduk Cingkam masih berada dalam situasi Miskin. Ada beberapa faktor yang menyebabkan situasi miskin masih diderita oleh penduduk setempat, seperti perangkat gampong yang masih kurang efektif bekerja, seperti istilah yang dipakai oleh bapak Aswan, "Mereka yang layak dapat bantuan, tak dapat, yang tidak layak mendapat bantuan, justru dapat." Istilah ini, mengindikasi permasalah dalam pemerintahan gampong. Elite gampong, seperti geuchik dinilai kurang adil dalam mendistribusi bantuan, dan terlibat dalam beberapa kasus penyimpangan program kerja, seperti tak kunjung selesainya jalan yang didanai PNPM menuju tempat pengambilan pasir. Padahal, menurut bapak Aswan, ada dana 80 juta rupiah yang dikucurkan oleh PNPM untuk pembangunan jalan, yang terealisasi hanya 50 juta rupiah, selebihnya (30 juta rupiah) sudah tidak ada kabar. Akibatnya, jalan yang seharusnya selesai 600 meter lagi, kini tak kunjung selesai. Menurut seorang petani sawit yang kami temui di jalan menuju lokasi sumber daya pasir tersebut, justru kepala 
project pembangunan jalan adalah geuchik setempat, menjadi sebab pembangunan jalan kemudian terlantar.

Selain itu, menurut bapak Aswan, ada persoalan lain yang menjadikan potret gampong sulit bangkit dari situasi miskin, yaitu ketidakmampuan warga mengelola sumber daya yang ada. "Rezeki ada, tapi tak tahu cara kami mengelola," demikian ungkapan yang sering dilontarkan warga. Setidaknya, jika dipetakan ada empat aset sumber daya lokal yang potensial, jika dikembangkan akan dapat membantu perekonomian warga. Pertama, danau dan waduk di Gampong Cingkam, yang dapat dimanfaatkan untuk pengembangan budidaya ikan air tawar. Kedua, debit dan sumber air bersih Gunung Solok, yang menjadi oase kehidupan warga sekitar. Bahkan, masyarakat Rimo punsangat tergantung pada debit air di Cingkam guna memenuhi kebutuhan minum sehari hari. Ketiga, pasir berkualitas di wilayah Cingkam, selama ini hanya dapat diangkut menggunakan sampan. Jika, jalan program PNPM selesai ke lokasi pasir, penduduk setempat akan dapat memanfaatkannya (tambang masyarakat) guna memenuhi tambahan kebutuhan ekonomi. Keempat, lahan perkebunan sawit, yang selama ini terkesan dikuasai oleh perusahaan yang sedang beroperasi di Aceh Singkil.

Pun demikian, menurut Salbiah (38 tahun), salah seorang warga Cingkam, jika dikelola dengan baik sumber natural yang ada di Cingkam, dapat menjadi penopang ekonomi warga. Ia mencontohkan ibunya yang telah memanfaatkan salah satu sumber daya (air bersih) yang ada di Cingkam, dengan menjual kepada pengusaha penjual air di Rimo, dan hasilnya sangat membantu pengembangan ekonomi. Setiap hari, dari penjualan air yang dilakukannya bagi warga Rimo, ia bisa mendapat keuntungan berkisar 150 ribu hingga 200 ribu rupiah. Namun, aktifitas ini hanya baru dikejakan oleh ibunya dan dua warga lain di Cingkam.

Sebagai komparasi, Minggu berikutnya, saya mengunjungi kampung yang juga dianggap paling parah kemiskinan di Kecamatan Gunung Meriah, yaitu Gampong Pertampakan. Jarak ke lokasi penelitian dari Rimo $\pm 8 \mathrm{Km}$. Gampong Pertampakan merupakan Gampong Relokasi pascatsunami sejak tahun 2007. Awalnya, mereka menetap di kawasan pinggir sungai, kemudian dipindahkan ke lahan pemerintah berdekatan dengan komplek Pesantren Tanah Merah (jarak dari lokasi lama ke lokasi baru adalah $6 \mathrm{KM}$ ). Lokasi wilayah gampong juga diapit oleh perkebunan sawit yang luas. 
Berdasar keterangan administrasi gampong, terdapat $70 \mathrm{KK}$ di Gampong Pertampakan, rumah tampak rapi tersusun, karena ini merupakan gampong relokasi. Pada awal relokasi, tahun 2007, ada 55 KK yang menetap di lokasi baru. Namun, hanya $40 \mathrm{KK}$ yang mendapat rumah bantuan permanen, selebihnya rumah yang kemudian dibangun secara swadaya masyarakat dan bermaterial kayu. Kini, sudah bertambah KK baru menjadi 70 KK. Namun, menurut geuchik, tak ada kecemberuan sosial, apalagi geuchik beserta perangkat gampong terus melakukan usaha dan upaya untuk mengonversi rumah swadara bermaterial kayu, dengan mangajukan bantuan pada pemerintah, guna dibangun secara permanen serupa rumah bantuan yang diterima $40 \mathrm{KK}$ sebelumnya.

Mata pencaharian penduduk Pertampakan adalah petani dan nelayan di sungai. Potensi gampong, hanya perkebunan dan ekosistem sungai, yang dapat dimanfaatkan warga untuk menopang kehidupan ekonomi mereka. Dari observasi yang kami lakukan, aroma dan atribut kemiskinan sangant ken tal di gampong ini. Beberapa rumah penduduk yang terbuat dari kayu, memang tampak kurang layak huni. Namun, solidaritas sosial mereka tampak baik, dapat dilihat dari beberapa bangunan kebutuhan bersama (mesjid, gedung rapat desa) dibangun secara swadaya, selain membangun beberapa rumah warga lain.

Persoalan lain paling mendasar di Gampong Pertampakan adalah rendahnya SDM setempat. Dari keterangan geuchik, sebagian besar penduduk gampong di sini hanya menamatkan SMP, jarang sekali yang melanjutkan ke SMA, apalagi ke tingkat Perguruan Tinggi. Diantara faktor terputusnya pendidikan adalah faktor ekonomi, yang menghalangi banyak remaja akhirnya terpaksa membantu orang tua di gampong. Faktor ini, kian mempermanenkan situasi masyarakat setempat, terus terpuruk dalam situasi kemiskinan. Selain itu, gempuran perusahaan sawit juga mempersempit ruang gerak masyarkat setempat, yang dikondisikan terus

\section{Upaya Reduksi Fenomena Kemiskinan (Pendekatan Kualitatif)}

Tentunya, sebuah kajian, penelitian, diharapkan akan melahirkan jalan, cara mengentaskan persoalan yang ada di tengah masyarakat. Pendekatan etnografi, diharapkan mampu memberikan ruang, celah mengintip bagi pengambil kebijakan, dalam upaya penyelesaian kemiskinan, dan tanpa mengenyampingkan interkoneksi metode, pengetahuan dan teknik pendekatan lainnya. Apalagi, sejak 
negara hadir, hingga sekarang, perang terhadap kemiskinan, terus ditabuh. Menurut Beni Setia Nugraha (Biro Humas Kemensos), bahwa selama ini untuk mengentaskan kemiskinan "dikeroyok" 19 kementerian. Target turun lima atau enam persen pada tahun 2019. Membangkitkan semangat juang orang miskin untuk bangkit, dengan meningkatkan ekonomi keluarga.

Mengingat kemiskinan merupakan masalah kemanusiaan, maka ia harus diselesaikan. Diantaranya adalah lewat upaya pengembangan masyarakat, sebagi bentuk komitmen dalam memberdayakan masyarakata lapis bawah (miskin, tak memiliki SDA, dan tak berdaya), diantaranya buruh, petani, nelayan, masyarakat hutan, pengangguran, cacat, marginal akibat gender, ras dan fisik. Diharapkan, dengan pemberdayaan mereka memiliki berbagai pilihan nyata menyangkut masa depan (Zubaedi, 2013 ; 4). Upaya pertama adalah mendiagnosis masalah kemiskinan dengan pendekatan ;

1. Individual Blame Approach, yaitu mencari sumber masalah kemiskinan pada pribadi si miskin (pendektan lima kapital), mekanisme ini hanya akan bisa dilangsungkan, jika mampu membangu komunikasi tanpa jarak, antara pribadi si miskin dan peneliti (butuh waktu lama).

2. Systme Blame Approach, mencari titik dan masalah kemiskinan pada level struktur sosial, yang akan menghasilkan alokasi dan penguasaan Sumber Daya yang timpang, kurang akses dalam pengambilan keputusan dan sejenisnya (Zubaedi, 2013 ; 108). Upaya kedua, menyangkut kebijakan, dan mengubah cara pandang pemerintah terhadap masyarakat. Pun, bagaimana seharusnya lembaga-lembaga pemerintah sinergi dalam melihat dan menyelesaikan masalah kemiskinan, tidak ada ketimpangan data, dan distribusi bantuan yang memungkinkan over lap. Maka, dalam mereduksi kemiskinan, kebutuhan dan jalan keluar dari kemiskinanharus benar-benar dipahami berdasar data akurat dan kultur.

Setelah tindakan mendiagnosis, harus dilanjutkan dengan proses pemberdayaan, seperti yang dikemukakan oleh United Nations (Mangata Tampu Bolon, 2001 ; 12-13 dalam Zubaedi, 2013) ada 11 teknik pemberdayaan, dua diantaranya yang dapat dilakukan secara langsung adalah;

1. Getting to Know the Local, yaitu mengetahui karakteristik masyarakat setempat (lokal), sebagaiman dilakukan dalam penelitian etnografi, yang membutuhkan waktu relatif lama-untuk mengenal dan 
memahami karakter masyarakat, sehingga proses advokasi dan kebijakan mereduksi kemiskinan-akan tepat sasaran.

2. Gathering Knowledge about The Local Community, mengumpulkan pengetahuan yang menyangkut informasi mengenai masyarakat setempat (Zubaedi, 2013 ; 77). Pengetahuan lokal sangat penting, karena semua sisi, termasuk ekonomi akan cepat berkembang, saat dilakukan pemberdayaan, penting memahami karekteristik masyarkat (pesisir dan pegunungan). Termasuk, di dalamnya bagaiman religi berperan-untuk mendongkrak etos kerja masyarakat.

Karena itu, tindakan mengentas kemiskinan, dalam perspektif budaya merupakan bagian dari gejala naluri manusia, yang terus ingin mempertahankan hidup, dan selalu tergantung pada orang lain (dalam hal ini, pada kebijakan pemerintah yang tepat sasaran) (Effendy, 2002 ; 2). Kebijakan berbasis penelitian (interkoneksi pengetahuan), akan mempercepat lajunya pembangunan, dan pengentasan masalah sosial, ekonomi seperti kemiskinan.

\section{Datar Bacaan}

Effendy, Onong Uchjana. 2002. Hubungan Masyarakat; Suatu Studi Komunitas. Bandung : PT Remaja Rosda Karya.

Idris, Safwan. 1997. Gerakan Zakat dalam Pemberdayaan Ekonomi Ummat. Jakarta : PT Citra Putra Bangsa.

Kusnadi. 2002. Konflik Sosial Nelayan ; Kemiskinan dan Perebutan Sumber Daya Perikanan. Yogyakarta : LkiS. 2003. Akar Kemiskinan Nelayan. Yogyakarta : LkiS.

Republika (Surat Kabar). 11 Desember 2014.

Siswanto, Budi. 2008. Kemiskinan, dan Perlawanan Kaum Nelayan. Malang : Laskbang Mediatama,

Strauss, Anselm \& Juliet Corbin. 2003. Dasar-dasar Penelitian Kualitatif Tatalangkah dan Teknik-teknik Teoritisasi Data. Yogyakarta: Pustaka Pelajar.

Utomo, Arif Punto. 2004. Negara Kuli ; Apalagi yang Kita Punya?. Jakarta : Republika. 
Community: Volume 1, nomor 1, Oktober 2015

Zubaedi. 2013. Pengembangan Masyarakat; Wacana dan Praktik. Jakarta : Kencana. 